\title{
Devlet ve Küresel Piyasa Arasında: Karadeniz Bölgesi'nde Küçük Ölçekli Fındık Üretimi
}

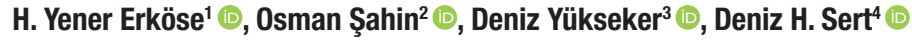

Öz

Türkiye dünyanın en büyük findıküreticisi ve ihracatçısı konumunda. Ancak findıküreticileri, bazı yıllar bol mahsul veya mahsullerine iyi fiyat alsalar bile, giderek daha zorlu koşullarda üretim yapıyorlar. Bu yazıda, Türkiye'de findık üretiminin barındırdığı çelişkileri ele alacağız. Sorunların kaynağında findık işletmelerinin küçük olmasının yattğı yönündeki genel kabulün aksine, sorunun aslen fındık piyasasındaki eşitsiz güç ilişkilerinden kaynaklandığını göstermeye çalışacağız. 2017'de Doğu ve Batı Karadeniz Bölgeleri'nde yaptı̆ı̆ız alan araştırmasının verilerinin bir bölümünün bulgularına dayanan makalede şu savları ortaya koyuyoruz. Türkiye'de küçük işletmelerde yapılan findık tarımının verimlilik ve kârlıık konusunda sorunları vardır. Fındık üreticilerinin çoğu verim artıımı için gerekli harcamaları ve yatırımı yapamamaktadırlar. Bu sorunlar, üretim birimlerinin küçük olmasından çok, findık üreticilerinin demografik profili, borçlanma ve findık piyasasındaki eşitsiz yapıdan kaynaklanmaktadır. Dolayısıyla, findık üretimindeki sorunların çözülmesi için üretim ölçeğini büyütmekten çok, eşitsiz güç ilişkilerinin hâkim olduğu küresel piyasada üretici lehine değişiklikler yapmak daha uygun olabilir.

Anahtar Kelimeler: Fındık üretimi • Karadeniz Bölgesi • Küçük meta üretimi • Küresel tedarik zinciri

Between the State and the World Market: Small-Scale Hazelnut Production in the Black Sea Region Abstract

Turkey is the world's largest hazelnut producer and exporter, yet hazelnut farmers have been growing hazelnuts in increasingly difficult conditions even for the years when production levels and hazelnut prices are high. In this paper, we take up the contradictions in hazelnut cultivation in Turkey and seek to show that, despite the commonsense opinion that the problem stems from small-scale cultivation, the more important problem is the unequal power relations that exist in the hazelnut market. We make the following arguments in the paper based on some of the findings from the field study we carried out in the Western and Eastern Black Sea regions in 2017. Issues exist regarding productivity and profitability in hazelnut cultivation characterized by small holdings. Hazelnut farmers are often unable to meet the expenditures and investments required for raising productivity. These problems arise more from the farmers' demographic profiles and debt levels and the unequal power relations in the hazelnut market with respect to small-scale production. Therefore, resolving the problems in hazelnut cultivation might require making changes that favor small farmers' power relations in the hazelnut market rather than enlarging holdings.

Keywords: Hazelnut cultivation • Black Sea region • Small-scale commodity production • Global supply chain

1 Sorumlu Yazar: H. Yener Erköse (Dr.), İzmir Ekonomi Üniversitesi, Fen ve Edebiyat Fakültesi Sosyoloji Bölümü, İzmir Türkiye. Eposta: yerkoese@gmail.com ORCID: 0000-0002-4108-2466

2 Osman Şahin (Dr.), Glasgow Caledonian University, Department of Economics and Law, Glasgow United Kingdom. Eposta: osman.sahin@gcu.ac.uk ORCID: 0000-0002-0815-9433

3 Deniz Yükseker (Prof. Dr.), İstanbul Aydın Üniversitesi, Küçükçekmece, İstanbul. Eposta: denizyukseker@aydin.edu.tr ORCID: 0000-0003-1047-1685

4 Deniz H. Sert, Koç Üniversitesi, Sosyal ve İnsani Bilimler Fakültesi Sosyoloji Bölümü, i̇stanbul Türkiye. Eposta: hsert@ku.edu. tr ORCID: 0000-0002-2660-3315

Attf: Erköse, H. Y., Şahin, O., Yükseker, D. ve Sert, D. H. O. (2020). Devlet ve küresel piyasa arasında: Karadeniz Bölgesi'nde küçük ölçekli findık üretimi. İstanbul Üniversitesi Sosyoloji Dergisi, 40, 55-77. https://doi.org/10.26650/SJ.2020.40.1.0047 


\section{Extended Summary}

Turkey is the world's largest hazelnut producer and exporter, but hazelnut farmers have been growing hazelnuts in increasingly difficult conditions. In this paper, we seek to show that, despite the commonsense opinion that the problems stem from small-scale cultivation, the more important problem is that unequal power relations that exist in the global hazelnut market.

Hazelnuts are an economically strategic commodity for Turkey and are cultivated in every province with a shore on the Black Sea. According to the Turkish Statistical Institute (TURKSTAT, 2020), Turkey makes up 70\% of the global production of hazelnuts. Still, issues are found regarding productivity and profitability in Turkey's hazelnut cultivation. The fundamental problems of productivity are the result of weather conditions, aging hazelnut trees and steep lands, the lack of care shown to hazelnut gardens, the farmers' aging demographic profile, limited mechanization, indebtedness, unequal power relations, and, according to the hazelnut producers, the prevalence of smallholdings.

Hazelnut production suffers from the lack of stable public policies. After creating the Farmer Registration System (ÇKS), the Turkish state essentially withdrew from the market, and since then prices have been set by the free market supply and demand curve (Ministry of Agriculture and Forestry, 2014). Following the bankruptcy of Fiskobirlik (Hazelnut Producers' Cooperative Union) in 2006, the government charged the Turkish Grain Board (TMO) with purchasing hazelnuts from the farmers until 2009. Thereafter, the new policy tool of "direct income support" for hazelnut garden owners has needed to be supported by TMO purchases occasionally due to fluctuations in prices. Nevertheless, because these ad hoc TMO purchases are informed by political considerations, they could not be effective tools in determining prices to protect the farmers.

In the era of developmentalism, the state had supported and protected farmers' smallholdings' petty commodity production (Aydın, 2009). After the world economic crisis in the 1970s, structural adjustment programs were implemented under the supervision of the World Bank and the International Monetary Fund, which limited the state's involvement in trade, investment, and finance in many countries. During globalization process, independent agricultural producers were integrated into the emerging global supply chains. The "global food regime," which is controlled by multinational companies (MNC) pushes one segment of small-scale farmers into an enlarging "circuit of casual labor" (McMichael, 2005, p. 266) while another segment becomes the supplier of raw materials to global agri-food corporations (Glenna, 2003; Bonanno, 2011). In developing countries, agricultural structures have been increasingly controlled by global supply chains while the small peasantry survives in a sea of uncertainties (Borlu, 2015; Borlu \& Matthews, 2018). Small-scale farmers cannot store their products and have to sell to the market at current prices that sometimes fall short 
of meeting their production costs. The gap between their income and costs each year contribute to their increasing indebtedness to agri-food companies (Borlu, 2015, p. 190).

In this article, we use the findings of our 2017 field research that was conducted in the Black Sea region in three provinces: Düzce, Sakarya, and Ordu. We conducted semi-structured interviews with 23 farmers, 13 local hazelnut merchants (manav), 53 seasonal agricultural workers, six labor contractors (dayıbaş1), two representatives of hazelnut cracking facilities, and nine representatives from local agencies. The qualitative features of our research make it difficult to draw generalizations. Still, certain trends are observable that the literature on hazelnut production supports.

Hazelnut garden owners getting older resulted in the farmers' increased dependence on seasonal agricultural workers (Levent et al., 2018). This is due to the farmers leaning toward having their children go through university education so they can have a stable income. Meanwhile, the unequal power relations between the farmers and the workers make the workers vulnerable, given that the latter are not legally protected due to lack of formal contracts (Levent et al., 2018).

The hazelnut market, while not competitive, does show the characteristics of an oligopsony where the global supply chain has few buyers but many sellers (Levent et al., 2018). In this market, small-scale garden owners who cannot store their product sell it to local merchants (manavs), who in turn sell it to cracking facilities and supplier firms. Manavs also act as moneylenders to the farmers who suffer from increased indebtedness. The farmers lack a collective organization and thus as individuals can only increase the area being cultivated in hope of better prices in future seasons.

The onset of the Agricultural Reform Implementation Project in Turkey after 2001 brought about the privatization of state monopolies in agriculture and created new market structures (İslamoğlu, 2017). The public mechanisms had failed to provide the crucial support the farmers needed, as the market structures were prevalent. The farmers were allowed to increase the area under cultivation, but without the institutional support that could have helped them increase productivity. The current structure maintains a cycle of low productivity and low prices that is only occasionally broken in some years when the yield is lower than usual due to weather conditions.

Despite the falling revenues, hazelnuts remain a major source of income for several hundreds of thousands of households. Accordingly, we think that the state should assume an active role in regulating the market and in creating support mechanisms to protect small farmers. Moreover, in addition to licensed warehousing, creating farmer collectives is also a must in order to limit supply and increase productivity on the registered lands that would empower the farmers in the market. These steps may help hazelnut production become more productive and sustainable, both financially and environmentally. 


\section{Devlet ve Küresel Piyasa Arasında: Karadeniz Bölgesi'nde Küçük Ölçekli Fındık Üretimi}

Türkiye dünyanın en büyük fındık üreticisi ve ihracatçısı konumunda. Ancak fındık üreticileri, bazı yıllar bol mahsul veya mahsullerine iyi fiyat alsalar bile, giderek daha zorlu koşullarda üretim yapıyorlar. Bu yazıda, Türkiye' de fındık üretiminin barındırdığı çelişkileri ele alacağız. Sorunların kaynağında findık işletmelerinin küçük olmasının yattığ1 yönündeki genel kabulün aksine, sorunun aslen küresel findık piyasasındaki eşitsiz güç ilişkilerinden kaynaklandığını göstermeye çalışacağız.

2017'de Doğu ve Batı Karadeniz Bölgeleri'nde yaptığımız alan araştırmasının verilerinin bir bölümünün bulgularına dayanan makalede şu savları ortaya koymaya çalışacağız. Türkiye' de küçük işletmelerde yapılan fındık tarımının verimlilik ve kârlılık konusunda sorunları vardır. Fındık üreticileri verim artırımı için gerekli harcamaları ve yatırımı yapamamaktadırlar. Ancak bu sorunlar, üretim birimlerinin küçük olmasından çok, fındık üreticilerinin demografik profili, borçlanma ve fındık piyasasındaki eşitsiz yapıdan kaynaklanmaktadır. Dolayısıyla, fındık üretimindeki sorunların çözülmesi için findık tarımı yapılan işletmeleri büyütmekten ziyade, eşitsiz güç ilişkilerinin hâkim olduğu küresel piyasada üretici lehine değişiklikler yapmak daha uygun olabilir.

Aşağıda öncelikle, Türkiye'de fındık üretiminin arka planına dair bilgi vereceğiz. Daha sonra, gelişmekte olan ülkelerde ve Türkiye'de tarımsal üretimdeki dönüşümle ilgili yazını kısaca özetleyeceğiz. Araştırma yöntemlerimizi açıkladığımız bölümden sonra, araştırmanın bulgularını sunacağız. Bu bölümde, fındık işletmelerinin özellikleri, fındık üreticilerinin özellikleri, üretim maliyetleri ve gelirler ve findık piyasasının yapısı üzerinde duracağız. Tartışma bölümünde ise, fındık piyasasında üreticiler açısından oluşan kısırdöngüyü vurgulamaya çalışacağız.

\section{Türkiye'de Fındık Üretimi}

Fındık, Türkiye ekonomisi için stratejik bir ürün. Öyle ki Türkiye'nin gerçekleştirdiği fındık ihracatı toplam tarımsal ürün ihracatının \%15-20'sine tekabül ediyor. Fındık ihracatı sadece 2019 senesinde 2 milyar dolarlık bir döviz girdisi sağlamış (Karadeniz İhracatçı Birlikleri, 2020). Fındık Türkiye'de başta Giresun, Ordu, Trabzon, Samsun ve Sakarya olmak üzere 33 ilde üretilebilen bir ürün. Türkiye' de findığın üretimi, büyük ölçekli işletmelerden ziyade küçük ölçekli aile işletmelerinde gerçekleşiyor. Dolayısıyla findığı sadece bir ekonomik ürün olarak değerlendirmek önemini kavramakta aslında yetersiz kalıyor. Fındık aynı zamanda, Karadeniz Bölgesi’nde hayatın vazgeçilmez bir parçası. Yerel nüfusun geçiminde ve göç örüntülerinde büyük önemi var. Dahası, fındık ağaçlarının eğimli bir yapıya sahip Karadeniz Bölgesi'nde erozyonun engellenmesine olan etkileri de yadsınamaz. Fındık, kuruyemiş olarak tüketilebildiği gibi aynı zamanda çikolata endüstrisinin de vazgeçilmez hammaddelerinden birisi. 
Tarım ve Orman Bakanlığı'nın düzenlediği Fındık Çalıştayı sonuç raporuna göre 2013 senesinde Türkiye' de yaklaşık 550.000 aile, 697.000 hektar alan üzerinde findık tarımı yapılıyordu. Fındık, genelde eğimin yüksek olduğu, çok yağış alan, nemli topraklarda yetiştiriliyor. Üretimin \%72'si Doğu Karadeniz Bölgesi’nde gerçekleşiyor (GTHB, 2014). 2014 senesinde çıkartılan bir Bakanlar Kurulu kararı ile fındık üretiminin 16 ile sınırlandırılması hedeflenmişti. Ancak bugün geldiğimiz noktada bu karar uygulanamamış ve findık, hala 33 ilde üretilmeye devam edilmektedir. 2018 rakamlarına göre, findık üretimi yapılan alan hala 705.000 hektar civarındadır (TMMOB Ziraat Mühendisleri Odası, 2018). Üretimin yoğunlaştığı iller sırasıyla Ordu (\%32), Giresun (\%17), Samsun (\%13), Sakarya (\%10), Trabzon (\%9) ve Düzce'dir (\%9) (GTHB 2014 yılı findık raporu, 2015). Yine aynı rapora göre bu ürüne bağlı olarak gelişen diğer iş kollarıyla beraber değerlendirildiğinde ise findık tarımının yedi ile sekiz milyon arasında insana bir şekilde gelir sağladığ 1 tahmin ediliyor (GTHB, 2014).

Türkiye'de fındık işleme endüstrisinin (kırma, kavurma, ezme vb.) çok geliştiğini söylemek mümkün. Bu bağlamda, Türkiye'nin ihraç ettiği fındığın \%37'sinin işlenmiş findık ve findık ürünleri olduğunu vurgulamak gerekiyor. Türk findığının en büyük alıcıları Almanya, İtalya, Fransa ve sonrasında Polonya, Avusturya, Kanada ve İsviçre'dir (GTHB, 2014).

TÜİK’e (2020) göre Türkiye, tarımsal üretimdeki dalgalanmalar göz önüne alındığında bile, dünyadaki fındığın \% 70'i kadarını üretiyor. Toprak Mahsulleri Ofisi’ne (TMO) göreyse son beş yıllık ortalamalar alındığında Türkiye, dünyadaki findığın yaklaşık \%62'sinin kaynağ TÜIKK rakamları, Türkiye'de findık üretimine ayrılan alandaki hızlı artış hakkında bize bilgi veriyor. 2000 senesinde Türkiye'de findık üretimine ayrılan alan 540.000 hektarken 2014 senesinde bu rakam 701.000 hektara kadar çıkıyor. 2018'den önceki beş yıllık verilere baktığımızda dünyadaki toplam findık üretim alanının yaklaşık 953.000 hektar olduğu görüyoruz (TMO, 2018). Bu da Türkiye'nin tek başına toplam findık üretim alanının neredeyse \%75'ini tek başına kontrol ettiği anlamına geliyor. Ancak üretimdeki ciddi dalgalanmaları istatistiklerden takip etmek mümkün. Örneğin, 2015 senesinde 683.270 ton findık üretilmişken 2016 senesinde bu rakam ciddi bir düşüşle 420.000 tona iniyor. $\mathrm{Bu}$ düşüşü, fındık üretimine ayrılan alanın azalmasıyla açıklamak mümkün değil. Zira her iki senede de findık üretimine ayrılan alan 700.000 hektar civarında (Giresun Ticaret Borsası, 2020). Bu düşüş, daha çok 2016 senesinde findığa negatif etkide bulunan kötü iklim koşullarıyla alakalı. Dolayısıyla Türkiye' de fındık üretiminin dış koşullardan (iklim, zirai hastalık ve haşere) çok fazla etkilendiğini söylemek mümkün.

Fındık tarımı için ayrılan tarımsal alanları üç kategoriye ayırmak mümkün:

a) 1. standart bölge (düşük verime sahip eski findık alanları): Ordu, Giresun, Trabzon, Rize ve Artvin 
b) 2. Standart bölge (eğimin daha az olduğu, daha fazla toprak derinliğine sahip, daha yeni ve daha fazla verime sahip findık alanları): Samsun, Sinop, Kastamonu, Zonguldak, Bolu, Düzce, Bartın, Sakarya ve Kocaeli

c) Fındığın sadece çerezlik olarak kısıtlı bir şekilde olarak üretildiği 25 il. Aralarında İstanbul ve Bursa gibi şehirlerin olduğu bu kategorideki şehirlerde üretilen findığın ciddi bir ihracat potansiyeli yok ve genel olarak üretildiği bölgede tüketiliyor.

Türkiye'de findık üretiminin en temel sorunlarından birisi verimlilik. Özellikle de ABD (hektar başına ortalama $2930 \mathrm{~kg}$ ), İtalya (hektar başına ortalama $1830 \mathrm{~kg}$ ) ve İspanya (hektar ortalama başına $1250 \mathrm{~kg}$ ) gibi ülkelerle karşılaştırıldığında Türkiye'de hektar başına ortalama olarak alınan verim, 2014 yılında 1. bölgede $760 \mathrm{~kg}$ civarındayken 2. bölgede $1110 \mathrm{~kg}$ civarında (GTHB, 2014). Bu durumun en önemli nedenlerinden birisi fındık ağaçlarının (ocakların) özellikle de Doğu Karadeniz Bölgesi’nde yaşlı ağaçlar olması. Bu bağlamda, ağaçların yenilenmesinin verimliliğin arttırılması için önemli bir adım olacağı açık. Aksi durumda, Türkiye'nin son yıllarda başka ülkeler lehine kaybettiği zeminin giderek artacağı aşikâr. Nitekim, bu bağlamda, Azerbaycan ve Gürcistan gibi ülkelerin daha genç ağaçlarla ve daha düşük üretim maliyetleriyle Türkiye'nin findık üretimine ciddi rakipler olarak ortaya çıktıklarını not etmek gerekiyor.

Verimliliğin düşük olmasına neden olan bir başka etmenin ise Türkiye'de fındık üretilen bahçelerin küçük olması olduğu belirtiliyor. Bir findık işletmesi için ideal büyüklük 22 dekar olarak öngörülürken Türkiye'de bu büyüklük 14 dekarı ancak buluyor (TMMOB Ziraat Mühendisleri Odası, 2018). Dolayısıyla küçük işletmelerin birleştirilmesinin, fındıkta verimliliğin arttırılması için önem arz ettiği öteden beri iddia ediliyor (örneğin GTHB, 2014).

Son olarak Türkiye toplumunun, ülkenin dünyanın en büyük findık üreticisi olmasına rağmen, düşük profilli findık tüketicisi olduğunu belirtmek gerekir. Türkiye'nin yıllık fındık tüketimi ortalama olarak 80.000 ton civarında seyrediyor. Yani dünyanın en büyük fındık üreticisi olan Türkiye'de kişi başına 1 kilogramın altında findık tüketimi gerçekleşiyor (Gümrük ve Ticaret Bakanlığı Kooperatifçilik Genel Müdürlüğü, 2017).

Stratejik öneme haiz olan findığın üretiminde istikrarlı bir devlet politikasının olduğunu söylemek mümkün değil. 2005 senesinde Çiftçi Kayıt Sistemi (ÇKS) sistemi getirildikten sonra devlet, findık piyasasını piyasa dinamiklerine bırakmış ve serbest piyasa koşullarında fiyatın arz-talep dengesi uyarınca belirlenmesinin önünü açmıştı (GTHB, 2014). Bundan önceki dönemlerde ise devlet, çeşitli tarımsal destek politikalarıyla findık tarımını destekliyordu. Özellikle de 1930'lar boyunca fındık üretimi devlet elitinin önem atfettiği bir kalem olmuştu. Örneğin, 1935 senesinde birinci ulusal findık kongresi devlet himayesinde toplanmıştı (Soysüren, 2017). Bu kongrede teşkilatlanma ve kooperatiflerin ve kooperatiflerin birlik halinde 
kurumsallaşmasının önemine dikkat çekilmişti. Kooperatifler ve kurumsallaşmış birlikler, üreticileri "tefecilerin, murabahacıların elinde kurtaracak" ve "birçok aracılar elinde müteessir olan findık ticaretini de intizam yoluna" sokacak kurumlar olarak işaret edilmiştir (Soysüren, 2017: 32).

Bu bağlamda özellikle de 1938 senesinde kurulan Fiskobirlik' in (Fındık Tarım Satış Kooperatifleri Birliği) önemli bir kurum olduğunu söylemek gerekir. Öyle ki 1980 sonrası dönemde, bazı senelerde Fiskobirlik toplam findık üretiminin yarısından fazlasının tek başına alıcısı durumundaydı. Dolayısıyla da Fiskobirlik aynı zamanda en büyük findık ihracatçısıydı. Ancak, 2001'de uygulamaya konan Dünya Bankası'nın Tarımsal Reform Uygulama Projesi uyarınca satış kooperatifleri kısmen özelleştirildi. Bu bağlamda, diğer birçok kooperatif gibi, Fiskobirlik de ciddi mali zorluklar yaşamaya başlayarak giderek daha az miktarda fındık almaya başlamıştı. Dahası, piyasanın diğer aktörleri, Fiskobirlik'e göre daha rekabetçi fiyatlar önerebiliyordu. Ancak Fiskobirlik' in deyim yerindeyse çöküşü 2006 senesinde üreticiden aldığı ciddi miktarlarda findığın parasını ödeyememesiyle gerçekleşti. Bu noktadan sonra Fiskobirlik’ in maddi olarak gücünü kaybettiği tescillenmiş ve dahası üreticinin bu kuruma olan güveni kaybolmuş oldu. Akabinde Fiskobirlik, piyasada fiyat belirleyici olma konumunu kaybetti. Nitekim bu krizin gerçekleştiği 2006 senesinde, devlet piyasaya tekrardan müdahale etmek gereğini duymuş ve TMO'yu üreticiden findık alımıyla yetkilendirmişti. 2009'a kadar da TMO, üreticiden fındık almaya devam etmişti. 2009 senesinde ise bu politika sonlandırıldı ve yerine "alan bazlı gelir desteği” getirildi. Bu sistemde devlet, üreticiye ürettiği findığın miktarından bağımsız olarak ÇKS sistemine kayıtlı bahçeleri için her sene ilan edilen sabit bir miktarı nakit olarak ödemektedir. Ancak, yine not etmek gerekirse, 2015 ve 2016 senelerinde gerçekleşen ciddi fiyat dalgalanmalarını takip eden 2017 senesinden itibaren devlet TMO vasıtası ile fındık alımı politikasını tekrar başlattı. Ne var ki var olan piyasa koşullarında TMO fiyat belirleyici bir aktör olmaktan uzak bir görünüm sergilemeye devam ediyor.

\section{Literatür Özeti}

Kapitalizmin temel süreçlerinden biri, her şeyin meta haline gelmesidir (Wallerstein, 1983). Dünya tarihinde aslen geçimlik olarak üretilen tarımsal ürünler ve tarım toprağı da zaman içinde bu metalaşma sürecine dahil olmuştur. Daha önce var olan toplumsal yapılar ve toplumsal ilişkiler bu genelleşen meta üretim düzeni içinde dönüştü. Sanayileşme sürecinde küçük meta üreticiliği içinde farklılaşma yaşandı (Bernstein ve ark., 2018). Bu farklılaşma içinde tarımsal metaların üretimine konu olan toplumsal ilişkilerin biçimini, üretilen tarımsal metanın biyolojik yapısı ve üretildiği arazinin coğrafi özellikleri olduğu kadar, devletin rolü, tarımsal üreticiye yönelik politikalar, siyasi çıkarlar ve veraset yasaları da belirler. Burada bir tarımsal ürünün ve üretildiği arazinin makineleşmeye uygunluğu kadar devletin hem siyasi hem de ekonomik 
çıkarlar sebebiyle küçük üreticiye desteğini devam ettirmesi ya da bu desteği sonlandırıp mevcut yapıların küresel pazar ilişkilerine entegrasyonunun önünü açması da önemli faktörler olarak karşımıza çıkar (Karaçimen ve Değirmenci, 2019, s. 68).

Tarımda küçük köylülük Osmanlı İmparatorluğu'ndan genç Cumhuriyet'e miras kalan yapılardan biridir (Keyder, 1987). Küreselleşmenin hızlandığı 1990'lara kadar, küçük köylülük, geçimlik tarım ve aile emeğine dayalı küçük meta üretimi temelinde devlet desteğiyle sürdüren bir tarımsal yapı söz konusudur. Bu yapıların uzun süre devam etmesinin temelindeki bir dönüm noktası Cumhuriyet'in ilk yıllarında Türkiye ile Yunanistan arasında gerçekleştirilen nüfus mübadelesinde ticari tarıma entegre Rum köylüsünün Anadolu'dan gönderilmesidir. Bir diğeri de 1946'da çıarılan Çiftçiyi Topraklandırma Kanunu'dur (Keyder, 1988). Pamuk ve Toprak (1988) sermaye karşısında köylülüğün çözülme ya da direniş dinamiğinin büyük ölçüde devlet politikaları ve endüstrileşme süreciyle belirlendiğinin altını çizmektedir.

Türkiye'de özellikle 1950-1980 döneminin merkezi planlamacı ve kalkınmacı devlet anlayışı çerçevesinde küçük köylülük desteklenip korunmuştur (Aydın, 2009). İthal ikameci sanayileşmenin ana politika olduğu bu dönem tarımda devlet tekelleri ve kooperatif birlikleri kapsamında üretim artışlarının yaşandığı bir zamandır. Üretim artışları yaşanırken devlet destekli mekanizmalarla ülke genelinde ürün ve emek pazarları yaygınlaşmıştır. Yine aynı dönemde henüz küresel sermaye girişi kısıtlı olsa da, daha yüksek kalite tohum, suni gübre kullanımı ve makineleşme tarımdan belirli bir nüfusu koparmaya başlamıştır (Yenal, 2001, s. 34-38). 1970'li yıllarda başlayan küresel krizin kalkınmacı devlet üzerine getirdiği borç ve enflasyon yükü IMF ile yapılan anlaşmalar sonucunda kalkınmacılık yerine enflasyonun önlenmesi ve ekonomide istikrar konularını ana hedef haline getirmiş (Köymen, 2008, s. 150-151) ve bundan sonra da tarımsal üretici ve tarımda çalışan işçi giderek piyasa ekonomisiyle karşı karşıya kalmıştır (Boratav, 2007, s. 145).

Birçok ülkede Dünya Bankası ve IMF'nin gözetiminde yürütülen yapısal uyum politikaları planlamacı devletin ticaret, yatırım ve finans alanındaki politika araçlarını kısıtlamıştır. Bu süreçte önü açılan tarım-gıda sermayesi tarım ile gıda üretimini birbirinden ayırarak, tarımsal üretim faaliyetini dönüştürmeye başlamıştır. Makineleşme, iletişim teknolojileri ve gıda üretimi için gerekli tarımsal ürün girdilerinin endüstriyel olarak işlenebilmesi ile bir 'küresel meta zinciri' ortaya çıkmaya başlamıştır (Aydın, 2009, s. 225).

Küreselleşme sürecinde, bağımsız tarım üreticileri de oluşan küresel zincirlerin parçası haline gelmeye başladı. Küresel boyutta faaliyet gösteren çokuluslu şirketler tarımsal süreçlerde hakimiyet kazandılar. Teknolojik dönüşümlere binaen küreselleşme döneminde topraktan geçinen küresel nüfus hızla azalmaya başladı; zira artık daha az toprak üzerinde daha az tarımsal üretici ile daha fazla gida üretilebilmektedir (Coleman, Grant ve Josling, 2004, s. 4). Çokuluslu şirketlere tabi 'küresel gida düzeni', küçük 
ölçekli üretim yapan çiftçilerin bir kısmını genişleyen bir 'gündelikçi emek çarkı' ve esnek istihdam döngüsü içine sokuyor (McMichael, 2005, s. 266). Bir kısmı ise, çokuluslu gıda şirketleri için üretim yapmaya başliyorlar.

Türkiye'de ise, liberal ve dışa açık bir ekonomik düzene 1980'de geçilmesinden sonra kırsal alanlarda yaşam standartları giderek bozulurken, devletin tarım sektörüne destekleri azaldı (Oyan, 2004, s. 49) ve tarım sektörünün GSYH ve istihdam içindeki payı hızla azald. Rakam vermek gerekirse, 1950-1959 döneminde tarımın GSYH'daki payı \%44,1 idi ve işgücünün \%78'i tarım sektöründeydi. 1990-1997 döneminde bu oranlar sırasıyla $\% 15,3$ ve $\% 45,6$ 'dır (age, s. 49). 2010 yılında işgücünün $\% 25,2$ 'si hala tarım sektöründeydi (TÜİK, 2010). 2018 y1lında sektörün GYSH'daki payı \%5,8'e düşmüştü (World Bank, 2019.) 2019 y1lında ise toplam istihdamın \%16,5'i tarımda yer alıyordu (TÜİK, 2019).

Yakın dönemde tarımsal alanlarla ilgili başka büyük sorunlar da ortaya çıktı. Metalaşma sürecinde gelinen aşamada kirlenme, tarım arazilerine inşaat yapılması ve erozyon sebebiyle Türkiye günümüzde tarım için ilave rezerv toprağı bulunmayan on dokuz ülke arasında yer almaktadır (Günaydın, 2008). Küresel tarım sermayesinin Türkiye'deki tarımsal yapılara yavaş nüfuz etmesi sebebiyle coğrafi olarak eşitsiz bir gelişim seyri gözlemlenmektedir (Keyder ve Yenal, 2011, s. 62-64). Bazı ürünlerde, genel olarak, liberalleşme sonrası aile işletmelerine devlet destek ve yardımlarının azalması çiftçileri sözleşmeli çiftçiler haline getiriyor (Aydın, 2009, s. 152,156).

Devlet kurumlarının pazarı düzenlemediği ve tarımın giderek 'sanayileştiği' bir durumda çiftçiler küresel tarım-gıda şirketlerine hammadde sağlayan tedarikçilere dönüşebiliyor (Glenna, 2003; Bonanno, 2011). Küresel pazarlar için üretim yapmanın sonucu farklılaşan küçük meta üreticiliği içinde kiracılık, yarıcılık ve tarım işçiliği gibi farklı işletme biçimleri oluşur (Karaçimen ve Değirmenci, 2019, s. 68). Farklı işletme biçimleri halinde de olsa üretim ilişkisi küçük meta üreticiliği olarak kalır (Boratav, 2004). Bu üretim biçimi mevsimlik tarım işçisi kullanmasına ve piyasa için üretime yönelik olmasına rağmen sermaye birikimi yapma imkânına genel olarak sahip değildir. Farklılaşma sonucu ortaya çıkan 'günümüz köylüleri kendilerine ancak küçük sermaye ve emek kaynakları tahsis edebilen, aynı zamanda hem önemsiz küçük kapitalistler hem de istihdam şartları üzerinde çok az söz sahibi olan işçiler biçimindeki 'küçük meta üreticileridir' (Bernstein, 1991) Sosyal ve ekonomik zitlıklar içeren bu durum birçok köylünün kırda yaşamaya devam etmesi ancak gelirlerini artıramamalarıyla sonuçlanmıştır (Akram-Lodhi ve Kay, 2010, s. 178).

Sadece tarımsal ürünler üretmek geçinmek için giderek yetersiz hale geldiği için, kırsal nüfusun tarım dışı gelir kaynaklarının çeşitlendiği gözlenmektedir. Hane içi emeğin tarım ya da tarım dışı düzensiz ücretli emekçi olarak çalışması, küçük ölçekli ticaret ve hizmet satışı ve göç eden hane bireylerinin yaptığı para transferleri bu gelir kaynakları arasındadır (Akram-Lodhi ve Kay, 2010). Wallerstein (1983) işverenlerin, 
tam proleterleşmiş hanelerde yaşayan işçilerden ziyade, yarı proleter hanelerin üyesi olan işçileri tercih edeceklerini öne sürmüştü (s. 27). Değerlenme ve maliyet riskini yayması, tarımsal emek sürecinde emek ve kalite denetimini kolaylaştırması ve ucuz işgücü avantajı bakımından, sermayenin, küçük üreticiler ya da başka bir deyişle aile çiftçilerini tercih ettiği belirtilmektedir (Bernstein, 2009, s. 115). Benzer şekilde çokuluslu tarım-gıda şirketlerinin de tedarikçileri olan küçük üreticilerin yarı-girişimci ve yarı-işçi halleriyle üretime katılmalarını tercih ettikleri söylenebilir.

Farklı coğrafyalardan küresel tarımsal meta zincirlerine eklemlenen tarımsal üreticilerin durumunda gözlemlendiği üzere yeni küreselleşme ve finansal birikim (Lapavitsas, 2009) döneminde kü̧̈ük ölçekli tarımsal üreticiler bir belirsizlikler deryası içinde de olsa var olmayı sürdürmektedir (Borlu, 2015; Borlu ve Matthews, 2018). Batı Anadolu mısır değer zinciri üzerine araştırmasında Borlu (2015), küçük üreticilerin endüstriyel mısır üretimine finansal birikimin araçları olan üretim kredileri kullanarak katıldıklarını tespit etmiştir (s. 174). Şirketlerin yönettiği üretim sürecine hammadde tedarikçisi olarak katılan küçük üretici bir tür "girişimci sömürüsü”ne tabi olur (Borlu, 2015, s. 178). Burada büyük ve küçük üretici arasındaki farklılaşmanın ayırt ediciliği ürünün depolanması ile alakalıdır. Ürününü depolayamayan küçük üretici ürünü bekletemez ve o anki pazar fiyatından elinden çıkarmak durumunda kalır, ancak bu fiyatlar küçük üreticinin üretim maliyetlerini karşılamaktan uzaktır. Üretim maliyeti ve elde edilen gelir arasında her geçen sene artan fark küçük üreticiyi tarım-gıda şirketlerine borçlu hale getirir (Borlu, 2015, s. 190). Borlu'ya göre bu borçluluk durumu toplam üretimin $\% 90$ 'ının elinde bulunduran mısır sanayiinin çiftçiyi sömürmesi dinamiğini besler (Borlu, 2015, s. 190; Borlu ve Matthews, 2018).

Mısırdan ve şeker pancarından farklı olarak çay üretiminde devlet desteği gerilemekle birlikte devam etmektedir. Türkiye'de üretilen çayın çok büyük kısmı ülke içinde tüketilmekte ve yalnızca \%2'si ihraç edilmektedir. Ürünün biyolojik özellikleri ve Türkiye'de üretildiği Doğu Karadeniz arazi yapısı makineleşmeye müsait değildir. Bölgedeki karmaşık veraset sistemiyle birlikte düşünüldüğünde makineleşmeye elverişsizlik geniş çaplı üretim yapan yapıların oluşmasını zorlaştırmaktadır. Tarihi sebeplere eklenen siyasi sebeplerle yüksek fiyatlı devlet alım desteği de devam etmiş ve küçük üreticilik korunmuştur. Bir tarımsal meta olarak çay yıl boyu bakım gerektirmeyen ve ancak belirli bir dönemde yaklaşık üç ya da dört aylık süreyle sürgün veren özelliğiyle üretim maliyeti de nispeten az olan bir üründür (Karaçimen ve Değirmenci, 2019, s. 69-78). Bütün bu şartlar göz önüne alındığında son yirmi yıllık dönüşüm sürecinde süregelen devlet desteğine rağmen çay üreticisi için de çaydan geçinme dönemi sona ermiştir. Çoğunluğu genişliği beş dönümün altındaki arazilerde yetiştirilen çaydan elde edilen gelir dönüşen hayat şartları ve enflasyon karşısında yetersiz kalmaktadır (Karaçimen ve Değirmenci, 2019, s. 77). 


\section{Yöntem}

Bu makalede, 2017 yılında Karadeniz Bölgesi'nde yapılan nitel alan araştırmasının bulguları kullanılmıştır. Alan araştırması, toplamda üç ilde (Düzce (Akçakoca), Ordu (Ünye ve merkez) ve Sakarya (Karasu)) ve iki kademede gerçekleştirilmiştir.

\section{Örneklem}

Alan araştırmasında, 23 fındık üreticisinin yanı sıra, 13 yerel fındık tüccarı (manav), 53 mevsimlik tarım işçisi, işçileri bölgeye getiren 6 dayıbaşı, 2 fındık kırma tesisi temsilcisi ve 9 yerel kurum temsilcisiyle, yarı yapılandırılmış mülakat tekniğiyle görüşmeler yapıldı. Alan araştırması nitel olmakla birlikte, seçilen sahaların yukarıda sözü edilen (Ordu'yu içeren) 1. ve (Düzce'yi içeren) 2. standart üretim bölgelerini temsil ettikleri söylenebilir. Bu çalışma, Adil Emek Derneği’nin (AED) sipariş ettiği bir araştırma için gerçekleştirildi. Söz konusu araştırmanın raporu, 2018 yılında yayınlandı (Levent, Yükseker, Şahin, Erköse ve Sert, 2018). Bu yazıda, fındık üreticileri ve manavlarla yapılan görüşmelerden elde edilen veriler kullanılmıştır. Fındık üreticisi 23 görüşmecinin sadece birisinin kadın olması araştırmanın önemli kısıtlarından birisi olarak görülebilirse de findık bahçelerinin genelde hanedeki erkekler üzerine olması nedeniyle kadınlarla görüşmekte zorluk yaşandı. Görüşülen fındık üreticilerinin hepsinin findık bahçeleri vardı. Bununla birlikte, görüşmeciler arasında kendi bahçelerinin yanı sıra yarıcılık yapan 3 üretici de yer alıyordu.

\section{Veri Toplama Araçları}

Mülakatlarda hane gelir stratejileri yaklaşımı kullanıldı. Bu bağlamda, mülakatlarda her türlü gelir kaynakları (findık ve diğer tarım üretiminden elde edilen gelirler, kiralar, kârlar, ücretler, geçimlik üretim, vb.) ve giderler, özellikle de findık üretiminin maliyeti hakkında sorular içeren soru kağıtları kullanıldı. Bununla birlikte, fındık üreticilerinin finansal okuryazarlığının farklı düzeylerde olması ve bazı görüşmecilerin mali konularda net bilgiler paylaşmaktan sakınması, gelir-gider yapıları konusunda toplanan verinin kalitesinde bazı sorunlara yol açtı. Fındık üreticilerine Türkiye'de fındık üretimi ve ihracatıyla ilgili sorunlar hakkındaki görüşleri de soruldu. Manavlara findık ticaretine ilişkin soruların yanı sıra fındık üretiminin genel koşulları hakkında da sorular yöneltildi. Konuşulan kişilerin rızası alınarak görüşmelerde ses kaydı alındı. Daha sonra araştırma ekibi tarafından transkripsiyonu yapılan görüşmeler, belirli temalar çerçevesinde kodlandı.

\section{Bulgular}

\section{Fındık İşletmelerinin ve Üreticilerinin Özellikleri}

Yaptığımız araştırmanın nitel olması itibariyle büyük genellemeler yapmak mümkün değil. Ancak, fındık üretimi konusundaki yazındaki verilerle de karşılaştırdığımızda, 
findık üretilen işletmelerin özellikleriyle ilgili bazı eğilimleri tespit etmek mümkün oldu. Özellikle iki tip üretici öne çıkıyordu. (1) Hane gelirinde fındık üretimi önemli bir kalem oluşturan ve küçük arazilerde üretim yapan çiftçiler. Bu haneler genelde yazın fındık köyde veya kasabada, kışın da fındık bahçelerine yakın il veya ilçe merkezlerinde yaşıyorlardı. (2) İstanbul, Ankara veya İzmir gibi büyük şehirlerde yaşayarak sadece yazın findık toplamak için memlekete dönen ve findık üretiminden gelen gelirin toplam gelirleri içinde görece düşük oranda olduğunu ifade eden üreticiler. Ancak yaygın kanının aksine, örneklemimizdeki üreticilerin büyük çoğunluğu findık bahçelerine yakın yaşayan hanelerdi.

Çeşitli raporlarda yer alan verilere dayanarak, Türkiye'de findık işletmelerinin ortalama büyüklüğünün 14-17 dönüm civarında olduğunu ve bu büyüklüğün 15-20 yıldır fazla değişmediğini (Doğanay 2012, Giresun Ticaret Borsas1 2020) söylemek mümkün iken, bizim örneklemimizdeki işletme büyüklüğü 20-1000 dönüm arasındaydı. İşletme büyüklüğünün ortancası ve en sık değeri ise 40 dönüm idi (bkz. Tablo 1). Ancak burada dikkat çekilmesi gereken birkaç önemli nokta var. Birincisi, bazı üreticiler ÇKS'ye kayıtlı tapulu bahçelerinin yanı sıra, 2B denilen orman vasfinı yitirmiş hazine arazilerinde de findık üretiyorlar. İkincisi, başkalarının kayıtlı arazilerini kiralayarak yarıcılık yapan işletmeler de mevcut ki bu işletmeler bizim örneklemimizde en büyük işletmeler idi. Üçüncüsü, bu işletmelerin çoğu parçalı idi. Diğer bir deyişle, bir üreticinin kimi zaman iki, üç ve hatta daha fazla yerde findık bahçesi vardı. Nitekim, parçalı olmaları, Türkiye' de tarım işletmelerinin önemli bir özelliğidir. 
Tablo 1

Fındık Üreticilerinin Hanehalkı Gelirleri

\begin{tabular}{|c|c|c|c|c|c|c|c|c|c|c|}
\hline 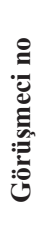 & 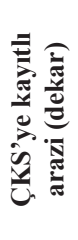 & 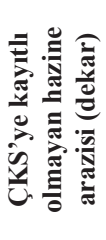 & 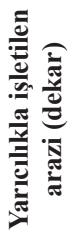 & $\stackrel{\infty}{\tilde{\sigma}}$ & 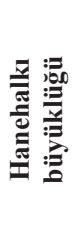 & 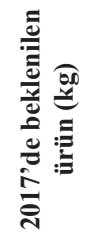 & 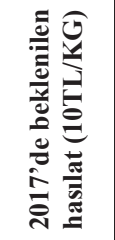 & 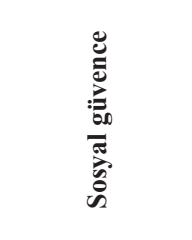 & 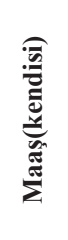 & 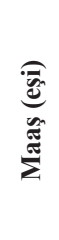 \\
\hline 1 & 12 & $\mathrm{X}$ & $\mathrm{x}$ & 60 & 2 & 500 & 5000 & Emekli & Yok & Yok \\
\hline 2 & 75 & $X$ & $\mathrm{x}$ & 50 & 5 & 11250 & 112500 & Emekli & Var & Var \\
\hline 3 & 60 & $X$ & 60 & 50 & 4 & 30000 & 270000 & Emekli & Var & Yok \\
\hline 4 & 10 & $X$ & 30 & 40 & 3 & 5200 & 32500 & Yeşil Kart & Var & Yok \\
\hline 5 & 30 & 20 & $\mathrm{x}$ & 52 & 5 & 5500 & 52250 & Evet & Var & Yok \\
\hline 6 & 11 & 11 & $\mathrm{x}$ & 61 & 4 & 4000 & 40000 & $\begin{array}{l}\text { Çocuğu bak- } \\
\text { makla yükümlü }\end{array}$ & Var & Yok \\
\hline 7 & 40 & $X$ & $\mathrm{x}$ & 38 & 4 & 5000 & 50000 & Evet & Var & Var \\
\hline 8 & 4 & $X$ & $\mathrm{x}$ & 48 & 4 & 800 & 8000 & Evet & Var & Yok \\
\hline 9 & 10 & 3 & $\mathrm{x}$ & 34 & 4 & 2500 & 25000 & Evet & Var & Yok \\
\hline 10 & 2 & $X$ & $\mathrm{x}$ & 25 & 4 & 150 & 1500 & Evet & Yok & Yok \\
\hline 11 & 14 & $\mathrm{X}$ & $\mathrm{x}$ & $\mathrm{x}$ & 5 & 2000 & 20000 & Emekli & Yok & Yok \\
\hline 12 & 40 & $\mathrm{X}$ & $\mathrm{x}$ & $\mathrm{x}$ & $x$ & $x$ & $x$ & Evet & Var & Var \\
\hline 13 & 100 & $\mathrm{X}$ & 900 & 38 & 3 & 100000 & 1000000 & Evet & Yok & Yok \\
\hline 14 & 57 & $\mathrm{X}$ & $\mathrm{x}$ & 50 & 4 & 10000 & 100000 & Emekli & Var & Yok \\
\hline 15 & 40 & $X$ & $\mathrm{x}$ & 58 & 4 & $\mathrm{x}$ & $\mathrm{x}$ & Evet & Var & Yok \\
\hline 16 & 65 & $\mathrm{X}$ & $\mathrm{x}$ & 55 & 6 & 16000 & 160000 & Yok & Yok & Yok \\
\hline 17 & 80 & $X$ & $\mathrm{x}$ & 44 & 6 & 15000 & 150000 & Evet & Yok & Yok \\
\hline 18 & 80 & $X$ & $\mathrm{x}$ & $\mathrm{x}$ & 7 & 15000 & 150000 & Evet & Yok & Yok \\
\hline 19 & 20 & $X$ & $\mathrm{x}$ & 51 & 2 & 3500 & 35000 & Yok & Var & Var \\
\hline 20 & 10 & $X$ & $\mathrm{x}$ & 67 & 2 & 1500 & 15000 & Emekli & Yok & Yok \\
\hline 21 & 40 & $X$ & $\mathrm{x}$ & 44 & 6 & 4000 & 40000 & Evet & Var & Yok \\
\hline 22 & 14 & $\mathrm{X}$ & $\mathrm{x}$ & 58 & 3 & 3000 & 30000 & $\begin{array}{l}\text { Çocuğu bak- } \\
\text { makla yükümlü }\end{array}$ & Yok & Yok \\
\hline 23 & 20 & $X$ & $\mathrm{x}$ & 50 & 4 & 1750 & 17500 & Yok & Yok & Yok \\
\hline
\end{tabular}

Kaynak: AED için hazırlanan rapordaki tablolardan uyarlandı

Fındık üreticilerinin bir diğer özelliği ise, çok genç bir nesli temsil etmemeleri. Örneklemimizde, yaşını beyan etmeyen 3 kişi dışında, sadece 4 kişi 40 yaşın altındaydı. Findık üreticilerinin yaşlanmakta olan bir grup olması birkaç sonuç doğuruyor. Çoğu görüşmecinin ifade ettiği gibi, ya gençler fındık işiyle uğraşmak istemiyorlar, ya da zaten ebeveynleri çocuklarının üniversite okuyup kentlerde iş bulmasını arzu ediyor. Bunun nedeni, bahçe sahibi ailelerin findık üretiminde gelir ve mali sürdürülebilirlik açısından bir gelecek görmemeleri. Gençlerin findıkla uğraşmaması ve üreticilerin genç olmaması, bahçede 12 aylık döngülerle yapılması gereken budama, gübreleme, ilaçlama, ot biçme, çapalama, bahçe temizleme ve findık toplama işleri için ücretli emek talebini ve maliyetini artıran unsurlar.

Türkiye'de mevsimlik göçmen tarım işçileri olmadan fındık hasadı yapılması mümkün değil (Levent ve ark., 2018). Ancak Türkiye'de findık üreticilerinin fındık 
hasadında çalışan mevsimlik tarım işçileriyle kurduğu ilişkinin asimetrik bir ilişki biçimi olduğunu vurgulamak gerekiyor. Örneklemek gerekirse her ne kadar son senelerde bu konudaki çabalar arttıysa da findık üreticileri ile mevsimlik göçmen tarım işçileri arasında yaptırım gücüne sahip sözleşmeler yapılmıyor (Levent ve ark., 2018). $\mathrm{Bu}$ durumun bir sonucu olarak herhangi bir anlaşmazlık durumunda mevsimlik göçmen tarım işçisi hukuken korumasız bir durumda kalıyor. Fındık hasat bölgelerine dayıbaşı denilen aracılar vasıtasıyla gelen mevsimlik göçmen tarım işçilerinin yaşadığı başka bir problem ise mevsimlik göçmen tarım işçilerinin çalıştıkları saat toplamının ve işçilerin hakedişlerinin düzenli bir şekilde kayıt altına alınmaması. Bu durum zaman zaman anlaşmazlıklara yol açıyor. Dahası, fındık üreticileri, işçilerin ödemelerini hasat sonunda yapıyor (Levent ve ark., 2018). Bu nedenle mevsimlik göçmen tarım işçileri, hasat sonuna kadar bölgede kalmak zorunda kalıyorlar. Bir diğer önemli mesele, mevsimlik tarım işçilerinin hasat süresindeki barınma koşullarının çok kötü olması. Bazı bölgelerde (özellikle Doğu Karadeniz'de) işçiler çadır kentlerde kalırken, bazı yerlerde ise findık bahçe sahiplerinin gösterdiği bakımsız ve temel ihtiyaçların karşılanmadığ 1 birimlerde kalmak zorunda kalıyorlar. Bir diğer sorun, aileleriyle birlikte hasada gelen mevsimlik tarım işçilerinin çocuklarının da çalışmasına -yani çocuk emeğine- bahçe sahiplerinin göz yumması.

Fındık üreticileri ve mevsimlik göçmen tarım işçileri arasındaki asimetrik ilişki üzerine daha çok şey söylenebilir. Ancak bu makalenin odağında findık hasadındaki emek ilişkileri olmadığı için o konuyu daha fazla detaylandırmayacağız. Emek maliyetinin yüksekliği ve emek ihtiyacının yıl içine yayılması nedeniyle pek çok üretici budama, ot biçme, gübreleme ve ilaçlama gibi verimi artırmak için gerekli ama zorunlu olmayan faaliyetleri atlıyorlar. Bu durum verimin düşmesine yol açıyor. Dolayısıyla, Türkiye'de fındık tarımındaki verim düşüklüğünün nedenleri arasında, arazilerin sarp olması gibi bir coğrafi nedenin yanı sıra, verim artırıcı işlemlerin eksik yapılması da yer alıyor.

Verimliliği düşüren bir diğer unsur ise makine kullanımının çok sınırlı olması. Hasat makinelerinin kullanımı, ancak büyük bahçelerde ölçek ekonomilerinden faydalanmaya imkân veriyor. Hatta toplam arazisi büyük ama parçalı ve özellikle de engebeli olan üreticiler için de hasat makinesi kullanmak çok etkin olmayabiliyor. Dolayısıyla, çoğu küçük üretici hasat makineleri yerine mevsimlik tarım işçilerine fındık toplattırmaya devam ediyor. Fındık üretiminde tırpan, ot biçme, ilaçlama gibi faaliyetlerin de kısmen mekanizasyonu mümkün. Tırpan ve ot biçme makineleri, elektrikli testere, traktöre takılabilecek bazı aparatlar ve harman makinesi bunların arasında. Ancak bunların kullanımı da çok fazla işgünü gerektirmese de kol gücü gerektiriyor. Daha yaşlı olan üreticiler bu işleri yapabilecek fiziki güçleri olmadığ i ç̧in yevmiyeli iş̧̧i kullanıyorlar. Öte yandan, bu aletlerin ve makinelerin alımı belirli yatırımları ve borçlanmayı gerektirdiği için, kâr marjı düşük olan pek çok üretici bu yatırımları yapmaktan imtina 
ediyor. Dolayısıyla, fındık üretiminde makineleşme, hem işletme büyüklüğü ve niteliği, hem de üretici hanelerin düşük emek arzı nedeniyle çok sınırlı kalıyor.

\section{Findık Üretiminde Maliyetler}

Fındık üretiminin maliyet yapısı ve findığın piyasada bulduğu fiyat, üreticileri en çok zorlayan konuların başında geliyor. Fındık üretiminin ana girdileri emek ve toprak. Bunları, gübre, ilaç, makine ve teçhizat ve mazot izliyor. Her hanenin hem çapalama hem de findık taşımak için kullandığı patpatlar ile traktörlerin kredi ödemeleri de önemli bir maliyet. Nitekim, örneklemdeki 23 üreticinin 11'i bankalara veya kişilere (manavlara) borçlu olduklarını beyan etti. Bunların dışında maliyetleri etkileyen başka faktörler de var. Örneğin arazinin daha dik ve engebeli olduğu Doğu Karadeniz Bölgesi’nde emek maliyeti daha yüksek (Levent ve ark., 2018). Aslında, üreticinin yaşı, sağlık durumu, ücretsiz aile emeğinin varlığı veya yokluğu ve bazı verim artırıcı faaliyetlerin atlanıp atlanmadığına göre, her findık üreticisinin kendisine özgü bir maliyet yapısı oluyor. Çiftçilerle görüşmelerimizden edindiğimiz bilgilerle hazırladığımız Tablo 2, 2017 yılındaki maliyetlere ilişkin bir fikir veriyor. 
Tablo 2

Fındık Üreticilerinin Tahmini Fındık Üretim Maliyetleri (2017 Yılı)

\begin{tabular}{|c|c|c|c|}
\hline \multicolumn{4}{|c|}{40 Ocaklık (ağaçlık) 1 dönüm arazi için (yılık değerlendirme) } \\
\hline \multicolumn{4}{|c|}{ HASAT ÖNCESİ TAHMINI MALIYET } \\
\hline Döngü & İș & Girdi maliyeti & Emek maliyeti \\
\hline Ekim & $\begin{array}{c}\text { Budama }+ \\
\text { budama sonrası temizleme }\end{array}$ & Yok & $150 \mathrm{TL}$ \\
\hline Kasım & Gübreleme & $70 \mathrm{TL}$ & $150 \mathrm{TL}$ \\
\hline Nisan-Ağustos & Ot İlacı & $15 \mathrm{TL}$ & - \\
\hline Nisan-Ağustos & Tirpanlama & Yok & $60 \mathrm{TL}$ \\
\hline Nisan & $\begin{array}{l}\text { Yaprak gübresi + mantar hastalığına } \\
\text { karşı ilaçlama }\end{array}$ & $47 \mathrm{TL}+16 \mathrm{TL}$ & 30 TL (günlük) \\
\hline Mayıs & $\begin{array}{l}\text { Bir önceki işin tekrarı + traktör } \\
\text { kullanımı }\end{array}$ & $\begin{array}{c}47 \mathrm{TL}+16 \mathrm{TL}+42 \\
\mathrm{TL} \text { (saatlik) }\end{array}$ & 15 TL (günlük) \\
\hline Nisan-Mayıs & Filiz alma & Yok & $130 \mathrm{TL}$ \\
\hline Haziran-Temmuz & Gübre + böcek ilacı & $26 \mathrm{TL}$ & 30 TL (günlük) \\
\hline Haziran-Temmuz & Tirpanlama & Yok & $90 \mathrm{TL}$ \\
\hline Haziran-Temmuz & Tirmıklama & Yok & $50 \mathrm{TL}$ \\
\hline İlave Maliyet** & $\begin{array}{l}\text { Budama aleti + böcek ilacı püskürt- } \\
\text { mek için gerekli benzin kullanımı }\end{array}$ & 65 TL (ortalama) & - \\
\hline \multirow[t]{3}{*}{ İlave Maliyet** } & Pırpır/Çapa Makinesi & $50 \mathrm{TL}$ & Yok \\
\hline & HASAT ZAMANI & & \\
\hline & İş & Girdi maliyeti & Emek maliyeti \\
\hline Ağustos-Eylül & Findik Toplama & Yok & $\begin{array}{c}60 \mathrm{TL} \text { x } 6 \text { (gerekli } \\
\text { işçi sayısı) }=360 \mathrm{TL}\end{array}$ \\
\hline \multirow[t]{2}{*}{ Ağustos-Eylül } & Patoz kullanımı & $\begin{array}{l}30 \text { TL (saatlik patoz } \\
\text { kiralama) }\end{array}$ & Yok \\
\hline & & $424 \mathrm{TL}$ & $1065 \mathrm{TL}$ \\
\hline TOPLAM & & & $\begin{array}{c}1489 \text { TL } \\
\text { (GIRDİ + EMEK) }\end{array}$ \\
\hline
\end{tabular}

Kaynak: AED için hazırlanan rapordaki tablolardan uyarlandı

Peki piyasada alınan fiyatlar, yukarıda açıkladığımız maliyetleri karşıladıktan sonra üreticiye ne kadar gelir getiriyor? 2017 yılının Ağustos ayında, TMO \%50 randımanlı (sağlam iç findıklı) levant tipi kabuklu fındığı 10 TL'den satın alacağını ilan etti. O zamana kadar görüşmüş olduğumuz çiftçiler bize, kilo başına 13-15 TL'nin maliyetleri kurtarıp makul bir gelir elde etmelerini sağlayacağını anlatmışlardı. Alan araştırmasının geri kalanında, çiftçilerin ilan edilen fiyattan duydukları memnuniyetsizliği sık sık işittik. TMO, ÇKS' de kayıtlı bahçelerde yapılan üretim üzerinden findık alımı yapıyordu. Bu yüzden üreticiler, 2B arazilerinde ürettikleri fındığı TMO’ya satamıyorlardı. Zaten TMO toplamda ne kadar alım yapacağını ilan etmişti (sezon sonunda gerçekleşen alım 136.000 ton oldu); bu durumda, gerçekteki findık rekoltesinin büyük bir kısmı için üreticilerin piyasada alıcı bulması gerekiyordu. Sonuç olarak, TMO'nun sunduğu fiyat piyasa için yol gösterici bir fiyat gibi görünse de aslında arzın (2017'de toplam findık rekoltesi 670.000 tondu) sadece bir bölümünü kapsadığı için sezon içinde findık fiyatı TMO’nun verdiği fiyatın altına düşecekti. Düzce'de yerel aktörler, geçmişte devletin 
“taban fiyat” belirleyerek yaptığı destek alımlarına gönderme yaparak, TMO'nun verdiği fiyatı alaycı bir şekilde "tavan fiyat" olarak niteliyorlardı. Yani sezonun geri kalanında çiftçilerin findık için alacakları fiyat 10 TL'nin üzerine pek çıkmayacaktı. O dönemden başlayarak Türk lirasının ABD doları karşısındaki değer kaybını göz önünde bulundurursak, aslında 2017 yılında belirlenen kilo başına fiyat, o yılın geri kalanında reel olarak da değer kaybetti. Benzer şekilde, 2018 (14 TL/kg) ve 2019'da (16,50 TL/ kg) TMO'nun verdiği alım fiyatları da yıl içinde reel olarak eridi.

\section{Fundık Üretiminde Piyasa İlişkileri}

Fındığın fiyatı, yukarıda özetlediğimiz literatürde belirtildiği gibi, Türkiye'deki bütün tarım ürünlerinde olduğu gibi piyasa ilişkileri içinde oluşuyor. Dolayısıyla, on binlerce üreticinin satıcı olarak yer aldığı bu piyasadaki diğer aktörlerin kimler olduğunu incelemeliyiz. Bu amaçla da findık üreticilerinin mamullerini satışa sunma sürecine göz atmak gerekiyor. Görüştüğümüz bahçe sahiplerinin çoğu, hasat edecekleri fındığa karşılık borç almış durumdaydılar. Buna, "fındığı dalında yemek" diyorlardı. Kimisi traktör veya başka araç kredi taksitlerini ödemek, kimisi oğlunu evlendirmek için borçlanmış durumdaydı. Dolayısıyla hasat yapılır yapılmaz ürünlerini satma peşindeydiler. Karadeniz Bölgesi'nde köylerde ve kasabalarda fındığı "manav" tabir edilen yerel toptancılar satın alıyor ve küçük bir kâr oranıyla büyük toptancılara ve fındık kırma fabrikalarına satıyorlar. Manavlar hem fındığı alan hem depolayan (emanet alan) hem de zaman zaman findık üreticilerine borç veren (ve iddialara göre kimisi tefecilik yapan) önemli yerel aktörler. Bahçe sahipleri, eğer çok büyük çiftçiler değillerse hasat ettikleri findığı depolama imkânları yok ve o yüzden manavlara satmak veya "emanete vermek" durumundalar. Manavlar lisanslı depoculuk yapan kişiler değil; sadece yer imkânları ölçüsünde depolama yapabiliyorlar. Depolama önemli bir mevzu; çünkü findığını depolayabilen üreticilerin sezon içinde findığa talep artması durumunda daha iyi bir fiyatla satış yapma imkânları doğuyor. Fakat çoğu bahçe sahibi bu imkâna sahip olmadığ i için, hasattan hemen sonra piyasada hâkim olan fiyata veya TMO'nun verdiği fiyata satı̧̧ yapmak zorunda kalıyorlar. Fındık hasadını manava emanete verdikleri takdirde manavın ne zaman ve hangi fiyattan satış yaptığı konusunda üreticilere yanlış bilgi vermesi ihtimali yüksek, çünkü bu konuda bir kayıt yok. Kısacası, eğer sezonun ilerleyen aylarında findık fiyatı yükselirse, manav emanet aldığı fındığın kazandığı değeri kendi kâr hanesine yazabiliyor.

Fındık üreticilerinin yüz yüze ilişki içinde olduğu kişiler manavlar iken, aslında piyasanın önemli aktörleri daha sonraki aşamalarda karşımıza çıkıyor. Manavlar ürünü fındık kırma fabrikalarına satıyorlar. Bu fabrikalar da kırılmış fındığı büyük tedarikçilere satıyor. Fındık kırma tesislerinin bazıları zaten büyük tedarikçilere ait. Türkiye'nin ihraç ettiği fındığın büyük kısmını birkaç büyük ulusal ve uluslararası tedarikçi firma satın alıyor. Onların findığı tedarik ettikleri firmalar ise, uluslararası şekerleme ve 
çikolata devleri. Diğer bir deyişle, findık piyasası aslında neoklasik iktisat teorisinin öngördüğü çok alııılı ve çok satııılı rekabetçi bir piyasa değil, az sayıda alıcının ve çok sayıda satıcının bir araya geldiği bir oligopsoni; diğer bir deyişle bir küresel tedarik zinciri (Levent ve ark., 2018).

Piyasa yapısı böyle iken, findık üreticilerinin bireysel olarak fiyatları belirlemede bir etkisi olamıyor. Fiskobirlik etkisini hem halk nezdinde hem de kurumsal olarak yitirdiği ve onun yerine geçecek başka bir üretici örgütlenmesi olmadığı için, findık üreticileri kolektif olarak da piyasa dengelerine müdahale edemiyorlar. Aslında üreticilerin, bireysel aktörler olarak yapabildikleri tek şey; gelecek sezon iyi bir fiyat oluşacağını umarak üretimi artırmak. Bu yüzden verimi düşük bahçelerde ve 2B arazilerine findık dikmiş durumdalar. Ancak bireysel bu eylemin kolektif etkisi, toplam ekili alanı ve dolayısıyla yıllık rekolteyi sürekli olarak yüksek tutmak oluyor. Sonuçta, arz yükselirken findığın uluslararası piyasadaki reel fiyatı giderek düşüyor.

\section{Findık Üreticilerin Gelirleri}

Yukarıda anlattığımız tablonun işaret ettiği gibi, findık üretimi, çoğu küçük ve orta ölçekli işletmeleri olan findık üreticileri için geçimlerini tamamen sağlayabildikleri bir faaliyet değil. Bununla birlikte, findıktan gelen gelir çoğu için elzem olmaya devam ediyor. Bu konuya hanehalkı gelir stratejileri kavramıla bakarak, ücret, kâr, kira, geçimlik üretim, transfer, vb. bütün gelir kalemlerini anlamaya çalıştık (Sert, Yükseker ve Açıalın, 2015; Smith ve Wallerstein, 1992). Görüştüğümüz çiftçilerin gelirleri hakkında verdikleri rakamsal bilgiler sağlıklı olmadığı için sadece gelir türleri üzerinden oluşturduğumuz Tablo 1'de görüldüğü üzere, findık üreten hanelerin birçoğunun başka gelirleri de var. Belirli bir yaşın üzerindekilerin emekli maaşı varken, kendisi veya eşi ücretli çalışanlar mevcut. Ücretli çalışanların ilçe ve il merkezlerindeki fabrikalarda veya hizmet sektöründe istihdam edildiklerini görüyoruz. Kira ve girişimcilik gelirleri kayda değer değil. Hanelerin yarısından azında geçimlik tarım üretimi var ki verdikleri bilgiye göre geçimlik üretim zaten çok sınırlı. Bunun bir nedeni yaşı ilerlemekte olan üretici hanelerin hayvanc1lık ve sebze-tahıl üretimiyle uğraşacak emek gücünün olmaması ise, diğer bir nedeni de her hanenin var olan bütün tarım arazisinde findık üretimi yapmayı tercih etmesi. Öte yandan, ÇKS'ye kayıtlı bahçeleri için üreticiler alan bazlı gelir desteği de alıyor. Ancak 2017 yılında dönüm başına yıllık 170 TL düzeyindeki bu desteğin, hanelerin geçimine kayda değer bir katkı sağladığını söylemek zor.

Bütün bu koşullar altında, findık üretimi küçük ve orta ölçekli işletmeler için kârlı bir faaliyet mi? Tablo 3’te, örneklem içinden seçilmiş (tam verisi olan) bazı işletmeler için verimlilik ve gider/gelir ve kârlılık hesaplarını görüyoruz. Burada fiyatları, 2017 yılında hasattan sonraki iki ayda, alan araştırması yapılan Düzce ve Ordu'da oluşan findık fiyatlarının ortalamasını kullanarak hesapladık. Maliyetleri ise, örneklemimizdeki seçilmiş işletmeler için üreticilerden aldığımız verilere dayanarak hesapladık. Tablo 
3’te görülebileceği üzere, Doğu Karadeniz Bölgesi'ni temsil ettiğini düşünebileceğimiz Ordu'da dönüm başı üretim maliyeti daha yüksek ve dolayısıyla kâr oranı daha düşük. Kârlılığın hem ölçek ekonomileriyle hem mekanizasyonla hem de arazi yapısıyla alakalı olduğunu söylemek mümkün. Tablo 3 ’te ayrıca, çok küçük ölçekli işletmeler için kârlılığın çok düşük olduğunu, hatta belirli bir arazi büyüklüğü altında negatif olduğunu görebiliyoruz. Aslında bu durum, küçük ölçekli fındık üreticilerinin neden verim artırıcı adımları (gübreleme, ilaçlama, ocak bakımı, makine kullanımı gibi) atamadığını da gösteriyor. Sonuç olarak, findık üreticileri bir kısır döngü içerisinde görünüyor.

Tablo 3

Beklenen Mahsul, Maliyet ve Gelir (2017 Yılı, Seçili Fındık Üreticileri)

\begin{tabular}{|c|c|c|c|c|c|c|c|c|}
\hline 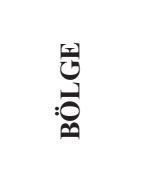 & 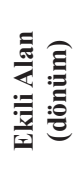 & 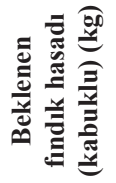 & 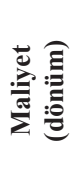 & 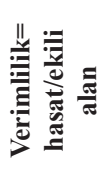 & 离 & : & : & 离 \\
\hline $\begin{array}{c}\text { AKÇA- } \\
\text { KOCA }\end{array}$ & 65 & 16000 & 970 & 246 & 0,254 & 2092 & 1122 & 72.950 \\
\hline $\begin{array}{c}\text { AKÇA- } \\
\text { KOCA }\end{array}$ & 40 & 6000 & 1045 & 150 & 0,144 & 1275 & 230 & 9.200 \\
\hline $\begin{array}{c}\text { AKÇA- } \\
\text { KOCA }\end{array}$ & 19 & 3500 & 598 & 184 & 0,308 & 1566 & 968 & 18.388 \\
\hline $\begin{array}{c}\text { AKÇA- } \\
\text { KOCA }\end{array}$ & 74 & 40000 & 912 & 541 & 0,593 & 4595 & 3683 & 272.512 \\
\hline $\begin{array}{c}\text { AKÇA- } \\
\text { KOCA }\end{array}$ & 20 & 3500 & 746 & 175 & 0,235 & 1488 & 742 & 14.830 \\
\hline $\begin{array}{c}\text { AKÇA- } \\
\text { KOCA }\end{array}$ & 80 & 15000 & 915 & 188 & 0,205 & 1594 & 679 & 54.300 \\
\hline $\begin{array}{c}\text { AKÇA- } \\
\text { KOCA }\end{array}$ & 10 & 1500 & 636 & 150 & 0,236 & 1275 & 639 & 6.390 \\
\hline $\begin{array}{c}\text { AKÇA- } \\
\text { KOCA }\end{array}$ & 14 & 3000 & 694 & 214 & 0,309 & 1821 & 1127 & 15.784 \\
\hline $\begin{array}{l}\text { AKÇA- } \\
\text { KOCA }\end{array}$ & 120 & 30000 & 417 & 250 & 0,600 & 2125 & 1708 & 204.960 \\
\hline $\begin{array}{c}\text { AKÇA- } \\
\text { KOCA }\end{array}$ & 12 & 500 & 377 & 42 & 0,111 & 354 & -22 & -268 \\
\hline $\begin{array}{c}\text { AKÇA- } \\
\text { KOCA }\end{array}$ & 14 & 2000 & 457 & 143 & 0,313 & 1214 & 757 & 10.602 \\
\hline ORDU & 4 & 900 & 1209 & 225 & 0,186 & 1913 & 704 & 2.814 \\
\hline ORDU & 2 & 250 & 1185 & 125 & 0,105 & 1063 & -123 & -245 \\
\hline ORDU & 16 & 2500 & 1082 & 156 & 0,144 & 1328 & 246 & 3.938 \\
\hline SAKARYA & 40 & 5000 & 982 & 125 & 0,127 & 1063 & 81 & 3.220 \\
\hline
\end{tabular}

Kaynak: AED için hazırlanan rapordaki tablolardan uyarlandı

\section{Tartış̧ma}

Bu bölüme, bir anekdotla başlamak istiyoruz. 2017 Ekim ayında alan araştırmasını tamamladıktan sonra sohbet etme firsatımız olan findık sektöründeki bir firmanın yetkilisi, ABD'de findık çiftliklerinin binlerce hektarlık düz arazilerde yer aldığını ve mülkiyetin 
az sayıda kişinin elinde olduğunu anlattı. Sohbetin başından itibaren Türkiye'de üretim ölçeğinin küçük olmasından yakınan yetkili, konuşmanın bir yerinde, Osmanlı döneminde de Anadolu'da küçük üreticiliğin başat olduğunu bir kitapta okuduğunu ve bu bilginin kendisini çok şaşırttığını söyledi. Fındık üretimindeki sorunların küçük üretim ölçeğinden ve parçalı arazi yapısına yol açan miras hukukundan kaynaklandığını, saha araştırması sırasında görüştüğümüz çoğu kurum yetkilisinden ve toptancılardan duymuştuk. Sanki araziler birleştirilse, bütün sorun çözülecekti. Burada bahsettiğimiz yetkili de bu düşünceye öyle kapılmıştı ki, Türkiye'de köylülüğün öteden beri küçük üretici olduğunu öğrenmek kendisini şoke etmişti. Türkiye'de Osmanlı'dan beri küçük köylülük yaygındı. Özellikle 1950'lerden itibaren köylüler tarımsal piyasalara entegre olarak küçük meta üreticileri haline geldiler (Keyder, 1988). Ancak 1980'lere ve hatta kısmen 2000'lere gelene kadar, bu üretim yapısı kamu politikaları (destek alımları, taban fiyatları) ve yapıları (Tekel, üretici birlikleri, vb.) üzerine oturuyordu. Bu yapılar, hem giderek kentleşen bir toplumun gıda ihtiyacını karşılıyor hem de tarım ürünleri ihracatını düzenliyordu.

Yazının ilk bölümünde bahsettiğimiz gibi, 2001 yılında başlatılan Tarımda Reform Uygulama Projesi ve tarımda devlet tekellerinin özelleştirilmesine ilişkin yasalar aracilı̆ııla, bu yapılar büyük ölçüde yıkılarak, yerine yeni piyasa yapıları oluşturuldu (İslamoğlu, 2017). Ancak hem yeni piyasa kurumlarının işleyişindeki sorunlar hem de 2007-2008'deki küresel mali krizin etkileri sonucunda hükümet, küçük tarım üreticilerinin talepleri yönünde piyasa kurallarını bir miktar gevşetti (age). Fındık üretiminde de benzer süreç, makalenin ilk bölümünde anlattığımız gibi 2006 yılından itibaren yaşandı. TMO'nun findık alımı yapmaya başlaması, üretim alanının kısıtlanmaya çalışılmasına rağmen sonradan bu kısıtlamalara uyulmaması, bu duruma örnek olarak verilebilir. Aslında TMO'nun rolünün, piyasa mekanizmalarının işletilip işletilmemesi konusundaki ikircikli bir halin yanı sıra, siyasetle ve özellikle popülist politikalarla da ilişkili olduğu söylenmeli (Gürel, Kü̧̈ük ve Taş, 2019). 2006'da Fiskobirlik'in yaşadığı kriz ertesinde Doğu Karadeniz'de findık üreticilerinin eylem yapması, seçmeni elinde tutmak isteyen hükümet için bir uyarıcıydı. Ertesi yıl, Temmuz ayındaki genel seçimler öncesinde hükümet fındık alım fiyatını yükseltti ve TMO yüksek düzeyde findık alımı yaptı. Aslında bu yazıda bulgularını paylaştığımız araştırmanın yapıldığı 2017 yılında da, Nisan ayındaki anayasa referandumu öncesinde hükümet TMO üzerinden yüklü miktarda findık alacağının işaretini vermişti (Gürel, Küçük ve Taş, 2019). Benzer şekilde 2019'daki yerel seçim tartışmaları (özellikle Karadeniz kökenli seçmenin etkili olacağı İstanbul Büyükşehir Belediye Başkanlı̆̆ı seçiminin tekrarı) sürecinde, bir kez daha TMO tarafından yüklü findık alımı yapılacağı açıklandı. Ancak burada vurgulanması gereken nokta şudur: TMO görece yüksek miktarda alım yapsa bile, piyasa koşullarını bu yazıda anlattığımız üzere büyük aktörler, yani büyük tedarikçiler ve uluslararası firmalar belirlemeye devam ediyor.

Literatür özetinde belirttiğimiz gibi, gelişmekte olan ülkelerde tarım üretimi giderek küresel tedarik zincirlerinin denetimine girdi. Öyle ki, 2000'lerin ortalarında yaşanan 
küresel gıda fiyat artışları sonrasında Dünya Bankası, küresel tedarik zincirlerini küçük üreticiliğin etkin ve verimli olmadığı gerekçesiyle gıda sorununa çözüm olarak önerebiliyordu. Halbuki küresel gıda sorununun ardında yatan neden gıda üretimindeki eksiklik değil, ürünlerin ihtiyacı olanlara ulaşmamasıydı (McMichael, 2009). Fındık örneğine dönecek olursak, fındık üreticilerinin dikili alanı büyütmelerine izin verildi, ama verimliliklerini artırmalarını sağlayacak kurumsal destekler verilmediği için üreticiler düşük verim ve düşük fiyattan oluşan bir döngüye girmiş bulunuyorlar. Bu koşullar altında, ancak iklim koşulları nedeniyle toplam üretim düşerse fiyatlar artabiliyor.

Fındık, girişte de belirttiğimiz gibi Türkiye için stratejik bir tarım ürünü. Fındıklı çikolata kreması ve fındıklı çikolata üretimi için küresel gıda firmaları tarafından talep edilmeye devam edecek olan bu ürünün üretim ve ihracattaki yerini koruması önem taşıyor. Bütün zorluklara rağmen küçük ve orta ölçekli üreticiler fındıktan vazgeçmiyorlar. Yüzbinlerce kişinin hane gelirlerinde kayda değer bir kalem oluşturan fındık üretiminin daha sürdürülebilir ve verimli hale getirilmesi için, piyasa örüntülerinde küçük üreticiyi koruyacak düzenlemeler yapılması gerektiğini düşünüyoruz. Burada sürdürülebilirliği hem ekonomik hem de çevresel açıdan kastediyoruz. Bu yazının konusu olmamakla birlikte, verim artırıcı emek- veya makineyoğun adımları atamayan üreticiler bahçelere iyi bakım yapamadıkları, dahası küresel ısınma nedeniyle aşırı yağışlar ve aşırı sıcaklar gibi iklim olayları daha sık yaşanmaya başladığı için fındık ağaçları mantar gibi hastalıklara ve bazı haşerelerin istilasına uğrayabiliyor. Hem bu çevresel faktörleri kontrol altına almak hem arzı kısıtlamak ve hem de kayıtlı arazilerde verimi artırmak için üretici örgütlenmeleri şart görünüyor. $\mathrm{Bu}$ yapıların, küçük üreticilerin sürdürülebilir tarım yapmaları için bilgi, malzeme, araç-gereç ve makine desteği verebilmeleri gerekir. Öte yandan, fındık üreticilerinin piyasada bir nebze güç kazanmaları için lisanslı depoculuk kurumunun bir an önce hayata geçirilmesi de önem taşımaktadır. Bu şekilde üreticiler, mamullerinin bozulması ve tüccarlar tarafından kandırılma tehdidi olmadan piyasada kendilerine daha uygun fiyat koşullarının oluşmasını bekleyebileceklerdir. Sonuç olarak, önerdiğimiz bu adımlar, hem üreticilerin güçlendirilmesini hem de devletin findık piyasasının düzenlenmesinde daha aktif bir rol üstlenmesini gerekli k1lmaktadır.

Teşekkür: Araştırmanın yapılması konusunda verdiği destek için Adil Emek Derneğine teşekkür ederiz.

Bildirimler: Bu çalışma, Adil Emek Derneği (FLA) için 2017'de gerçekleştirilen saha araştırmasının sonucunda ortaya çıkan "Hazelnut Barometer: Price Procurement Study" (2018) başlıklı rapora dayanmaktadır.

Hakem Değerlendirmesi: Dış bağımsız.

Çıkar Çatışması: Yazarlar çıkar çatışması bildirmemiştir.

Finansal Destek: Yazarlar bu çalışma için finansal destek almadığını beyan etmiştir.

Peer-review: Externally peer-reviewed.

Conflict of Interest: The author declares no potential conflicts of interest with respect to the research, authorship, and/or publication of this article.

Grant Support: The author received no financial support for the research, authorship, and/or publication of this article. 


\section{Kaynakça/References}

Akram-Lodhi, A. H., \& Kay, C. (2010). Surveying the agrarian question (Part 1): Unearthing foundations, exploring diversity. The Journal of Peasant Studies, 37(1), 177-202.

Aydın, Z. (2009). De-agrarianization and de-peasantization: Dilemmas of neo-liberal restructuring in Turkish agriculture. In Z. Öniş ve F. Şenses (Eds.), Turkey and the global economy: Neo-liberal restructuring and integration in post-crisis era (pp. 223-242). Routledge.

Bernstein, H. (1991). Petty commodity production. In T. Bottomore, L. Harris, V. G. Kiernan, \& R. Miliband (Eds.) A dictionary of Marxist thought (2nd ed., pp. 417-419). Blackwell.

Bernstein, H. (2009). Tarımsal değişimin sınıfsal dinamikleri (O. Köymen, çev.). Yordam.

Bernstein, H., Friedmann, H., van der Ploeg, J. D., Shanin, T., \& White, B. (2018). Fifty years of debate on peasantries, 1966-2016. The Journal of Peasant Studies, 45(4), 689-714.

Boratav, K. (2004). Tarımsal yapılar ve kapitalizm. İmge.

Boratav, K. (2007). Türkiye iktisat tarihi, 1908-2005. İmge.

Borlu, Y. (2015). A story of post-Fordist exploitation: Financialization and small-scale maize farmers in Turkey. Rural Sociology, 80(2), 173-197.

Borlu, Y., \& Matthews, S. (2018). Industrial maize as a commodity system: Spatial scale and relations of production in Turkey's agricultre after economic restructuring. Tijdschrift voor Economische en Sociale Geografie, 109(5), 629-643.

Coleman, W., Grant, W., \& Josling, T. (2004). Agriculture in the new global economy. Edward Elgar Publishing.

Doğanay, H. (2012). Türkiye findık meyvacılığındaki yeni gelişmeler. Doğu Coğrafya Dergisi, 27, 1-22.

Gıda, Tarım ve Hayvancılık Bakanlığı (2014). Fındık çalıştayı sonuç raporu. http://www.tb.org.tr/ dosya/findik_calistay_sonuc_raporu2013_trabzon.pdf

Giresun Ticaret Borsas1 (2020). Üretim sahalarl tablosu. http://www.giresuntb.org.tr/ FindikDikimAlanlari

Giresun Ticaret Borsas1 (2016). Türkiye findlk ihracat verileri. http://www.giresuntb.org.tr/ IhracatVerileri

Glenna, L. (2003). Farm crisis or agricultural system crisis? Defining national problems in a global economy. International Journal of Sociology of Agriculture and Food, 11, 15-30.

Gümrük ve Ticaret Bakanlığı Kooperatifçilik Genel Müdürlüğü (2017). http://koop.gtb.gov.tr/data /5ad06bb9ddee7dd8b423eb23/2017\%20F\%C4\%B1nd\%C4\%B1k\%20Raporu.pdf

Gümrük ve Ticaret Bakanlığı Kooperatifçilik Genel Müdürlüğü (2015). 2014 Yılı Fındık Raporu. http://koop.gtb.gov.tr/data/53319cec487c8eble43d7299/2014\%20F\%C4\%B1nd\%C4\%B1k\%20 Raporu.pdf

Günaydın, G. (2008). Türkiye tarımı ve değişme eğilimleri. TMMOB Ziraat Mühendisleri Odası. http://www.zmo.org.tr/genel/bizden_detay.php?kod=8875\&tipi $=38 \&$ sube $=0$

Gürel, B., Küçük, B., \& Taş, S. (2019). The rural roots of the rise of the Justice and Development Party in Turkey. The Journal of Peasant Studies, 46(3), 457-479.

İslamoğlu, H. (2017). The politics of agricultural production in Turkey. In F. Adaman, B. Akbulut, \& M. Arsel (Eds.), Neoliberal Turkey and its discontents: Economic policy and the environment under Erdogan (pp. 75-102). IB Tauris.

Karaçimen, E., \& Değirmenci, E. (2019). Doğu Karadeniz'de çay tarımının çelişkili sürekliliği. Toplum ve Bilim 150, 63-93. 
Karadeniz İhracatçıları Birliği (2020). Fındık istatistikleri. http://www.kib.org.tr/tr/ihracat-istatistiklerfindik-istatistikleri.html

Keyder, Ç. (1987). State and class in Turkey. Verso.

Keyder, Ç. (1988). Türk tarımında küçük meta üretiminin yerleşmesi (1946-60). Ş. Pamuk \& Z. Toprak (Ed.), Türkiye'de tarımsal yapılar kitabı içinde (s. 163-175). Yurt Yayınları.

Keyder, Ç., \& Yenal, Z. (2011) Agrarian change under globalization: Markets and insecurity in Turkish agriculture. Journal of Agrarian Change, 11(1), 60-86.

Köymen, O. (2008). Kapitalizm ve köylülük. Yordam Kitap.

Lapavitsas, C. (2009). Financialised capitalism: Crisis and financial expropriation. Historical Materialism, 17(2), 114-148.

Levent, H., Yükseker, D., Şahin, O., Erköse, H. Y., \& Sert, H. D. (2018). Hazelnut barometer: Price procurement study. Washington, DC: Fair Labor Association. https://www.fairlabor.org/sites/ default/files/documents/reports/hazelnut_baramoter_price_study.pdf

McMichael, P. (2005). Global development and the corporate food regime. In F. H. Buttel \& P. McMichael (Eds.), New directions in the sociology of global development: Research in rural sociology and development (Vol. 11, pp. 265-299). Emerald.

McMichael, P. (2009). Banking on agriculture: A review of the World Development Report 2008. Journal of Agrarian Change, 9(2), 235-246.

Oyan, O. (2004). Tarımsal politikalardan politikasız bir tarıma doğru. N. Balkan \& S. Savran (Ed.), Neoliberalizmin tahribatı: 2000'li yıllarda Türkiye kitabı içinde (C. 2, s. 44-67). Metis.

Pamuk, Ş., \& Toprak, Z. (1988). Sunuş. Ş. Pamuk \& Z. Toprak (Ed.), Türkiye'de tarımsal yapılar kitabı içinde. Yurt Yayınları.

Republic of Turkey Ministry of Agriculture and Forestry (2014). Fındık Çalıştayı Sonuç Raporu. http://www.tb.org.tr/dosya/findik_calistay_sonuc_raporu2013_trabzon.pdf

Sert, H. D., Yükseker, D., \& Açıkalın, A. (2015). Ístanbul'da hanelerin geçinme yöntemleri: Proleterleşme, ücret bağımlılı̆̆ı ve güvence(sizlik). Friedrich Ebert Stiftung Derneği.

Smith, J., \& Wallerstein, I. (1992). Households as an institution of the world economy. In J. Smith \& I. Wallerstein (Eds.) Creating and Transforming Households: The Constraints of the World Economy (pp. 3-26). Cambridge University Press.

Soysüren, A. H. (2017). Erken Cumhuriyet Dönemi'nde devlet'in rolü bağlamında findık piyasasının örgütlenmesi ve ihracatçı tüccarların ayrışması sürecinde Karadeniz Fındık İhracatçıları Birliği'nin kurulması. Ünye İ̈BF Dergisi, 1(2), 26-42.

TMMOB Chamber of Agricultural Engineers (2018). Findık raporu - 2018. http://www.zmo.org. tr/genel/bizden_detay.php?kod=30070\&tipi $=5 \&$ sube $=0$

Turksih Grain Board (2018). 2018 yll findlk sektör raporu. http://www.tmo.gov.tr/Upload/Document/ findiksektorraporu2018.pdf

Turkish Statistical Institute (2020). http://www.tuik.gov.tr/PreTablo.do?alt_id=1001

Turkish Statistical Institute (n.d.). Temel istatistikler. http://www.tuik.gov.tr/UstMenu. do?metod=temelist

Wallerstein, I. (1983) Historical capitalism. Verso.

World Bank (n.d.). Agriculture, forestry, and fishing, value added (\% of GDP), 1960-2018. https:// data.worldbank.org/indicator/NV.AGR.TOTL.ZS

Yenal, Z. N. (2001). Türkiye'de tarım ve gıda üretiminin yeniden yapılanması ve uluslararasılaşması. Toplum ve Bilim, 88, 32-54. 
